\title{
AZ OROSHÁZI KISTÉRSÉG KÖZÉPISKOLÁINAK BEISKOLÁZÁSÁVAL KAPCSOLATOS FELMÉRÉS A 2011/2012-ES TANÉVBEN
}

\author{
Zsótér Brigitta - Kapu Fanni Anikó
}

\begin{abstract}
SUMMARY
Since the political transformation the Hungarian educational system has overgone many changes as an effect of the permanent modification of public education law. As a result, significant differences in performance can be observed between the different school types. The role of grammar and technical schools have increased, meanwhile the value of vocational schools has been socially reduced. We made a survey among the pupils of 9th form in the four secondary schools found in the small region of Orosháza in order to see what factors affect their choice of school. The most important factors proved to be the future plans, proximity of the living place, parents' social position and the social conditions of the family. As a result of our research we got an overall picture of the training opportunities hidden in the region, pupils'motivation and factors which determine their choice.
\end{abstract}

\section{BEVEZETÉS}

A kutatás témája az Orosházi kistérség középiskoláinak - Orosháza és Tótkomlós beiskolázásával kapcsolatos felmérés, melyben a térség négy középfokú oktatási intézménye kerül bemutatásra.

A választást az motiválta, hogy olvastunk néhány érdekes tanulmányt a 2000-es évek PISA ${ }^{32}$ méréseiről, különösen a társadalmi-gazdasági környezet és a tanulói eredményesség, valamint az iskolaválasztási szokások összefüggéseiben. A három évenként megtartott kutatások során, a tizenöt éves tanulók olvasási, matematikai, és természettudományos műveltségét vizsgálják. A közzétett eredményekből megállapítható, hogy Magyarország egyre rosszabb helyet foglal el ezen a ranglistán (Róbert 2004). Az általános iskola befejezését követően a diákoknak dönteniük kell arról, hogy az elkövetkező néhány évben milyen típusú középfokú oktatási intézményben szeretnének továbbtanulni. Az iskola kiválasztását számos tényező befolyásolhatja, de mi lehet ezek közül a legmeghatározóbb? Ezzel kapcsolatban (a vizsgált középiskolák tanulóira vonatkoztatva) felállítottunk néhány hipotézist, amelyeket a kutatás során próbáltunk bizonyítani:

1. A vizsgált közoktatási intézményekben, ahol általános iskolai oktatás is folyik, a diákok általában a középiskolai tanulmányaikat is ott folytatják.

2. Az iskola kiválasztásában szerepet játszik, hogy a nagyszülők és szülök is ugyanabban az intézményben tanultak.

3. A középiskolai képzési forma kiválasztásánál döntő tényező a tanulók iskola befejezése utáni tervei.

4. A jó hírnévvel rendelkező oktatási intézmények vonzzák az Orosházi kistérségen kívüli települések diákjait.

32 Programme for International Student Assessment (Tanulói Teljesítmények Nemzetközi Értékelésének Programja) 
5. A középiskolába való jelentkezést a szülők társadalmi pozíciója befolyásolja.

6. Meghatározó tényező a beiskolázásnál a család szociális helyzete.

\section{ANYAG ÉS MÓDSZER}

A primer kutatási technikák módszerei Majoros (2004) szerint: megfigyelés, kísérletek, kérdőíves vizsgálatok, interjú, terepkutatás. Ezek közül a kérdöíves módszert választottuk.

Horváth (2004) és Andor (1998) módszertani leírása alapján végeztük el a kérdőívek tartalmi összeállítását. Módszertani kérdőíves szerkesztési elvünket a következőkben foglaljuk össze:

- A kutatást megkezdése elött mindig ki kell tüzni a kutatás célját, vagyis azt, hogy mit is szeretnénk megtudni a kérdőív kitöltetése által.

- A következő lépés, hogy kiválasszuk az alapsokaságot, akiknek a körében vizsgálódunk.

- A kérdőív összeállítása során pontosan meg kell fogalmaznunk a kérdéseket, hogy egyértelmü legyen mindenki számára, hogy mire is vagyunk kíváncsiak.

- Gyakran előfordul, hogy a vizsgálandó kérdést nem lehet egyetlen egy kérdésként feltenni, hanem sok kis részkérdés formájában tesszük fel, amely ugyanahhoz az eredményhez fog majd vezetni.

- Az elkészült kérdőívet véglegesítés elött ellenőrizzük, és végezzünk szük csoportban próbamérést.

- Ha a kitöltés sikeres volt, utólagos megbeszéléseket folytatunk, majd végezetül engedélyezzük a szükséges példányszámban való megjelenését.

- A kérdőív készítése során a kérdéseket sorrendben célszerü feltenni.

- Egy rövid általános bevezetővel indítunk, hogy milyen célból készült, hogy mit vizsgálunk, és mit akarunk a kitöltésével elérni.

- Ezt követik a bemelegítő kérdések, melyek rávezetnek a témára, így könnyen megválaszolhatóak.

- A fö kérdések már konkrétan az adott problémára irányulnak.

- A végét demográfiai vonatkozású kérdésekkel zárjuk, - melyek a kutatás szempontjából a leglényegesebb információkat szolgáltatják - mert ekkorra már kialakul a válaszadókban az irántuk érzett bizalom.

- A szerkesztés során különböző típusú kérdések közül választhatunk. Előnyös, ha minél több fajtát alkalmazunk.

- A leggyakrabban használt kérdéstípusok: a nyitott és a zárt. A nyitott kérdések esetében a véleményünket saját szavainkkal fogalmazzuk meg, ahogyan a hétköznapokban is beszélünk. A zárt kérdéseknek két típusa van: eldöntendő vagy feleletválasztós. E két fajta között csupán annyi a különbség, hogy az előbbinél két válaszlehetőség közül kell választani, míg az utóbbinál, kettőnél több közül (Horváth 2004). 
A 2011/2012-es tanév második félévének elején egy kérdőíves felmérést készítettünk az Orosházi kistérség 4 középiskolájában. A kitöltés önkéntesen zajlott, név nélkül, osztályfőnöki óra keretein belül. A kérdőív összesen 30 kérdésből állt, nyitott és zárt típusúakból egyaránt, és öt fö témakörre fókuszált. A vizsgálatunk során 468 fö részére osztottunk ki kérdöívet, melyből 404db-ot kaptunk vissza kiértékelhető formában. A kutatásban a térség 9. osztályos tanulóit kérdeztük meg. A kérdőívben arra törekedtünk, hogy feltérképezzük milyen szempontokat mérlegeltek a középiskola megválasztása előtt és mik az elképzeléseik, terveik az iskola elvégzése után. Valamint vizsgáltuk általános iskolai tanulmányi eredményeiket, a családjuk szociális helyzetét, a szüleik társadalmi pozícióját, hogy ezek mennyire befolyásolták a választásukat.

A kérdőívek feldolgozása és kiértékelése a SPSS Statistics nevü program segítségével történt, mellyel nagyméretü és összetett adatbázisokat lehet feldolgozni gyorsan és hatékonyan. A program magába foglalja a legmodernebb statisztika eljárásokat az adatbázis kezeléstől, a leíró statisztikán keresztül a legbonyolultabb többváltozós matematikai statisztikai eljárásokig (Huzsvai 2011).

\section{VIZSGÁLATI EREDMÉNYEK ÉRTÉKELÉSE}

A legtöbb kérdőívet a Tisza Kálmán Közoktatási Intézményben töltötték ki. Itt 174 diák segítette a munkánkat a válaszaival. Ebböl 93 fỏ szakközépiskolai osztályba jár, 81 fő pedig szakiskolába. A legkisebb arányt a Jankó János Általános Iskola és Gimnázium képvisel, itt mindösszesen csak 29 diák töltötte ki a kérdőívet. Ezen kis százaléknak az oka, hogy ebben az intézményben csak egy 4 évfolyamos gimnáziumi osztály van. A Tisza Kálmán Közoktatási Intézményben eltér a tanulók átlagéletkora a többi intézményben felvett adatoktól. Ez abból következhet, hogy itt szakiskolai képzés is folyik, és a szakiskolai programban jelentős az osztályismétlök száma. A vizsgált populációban - minden iskola esetén magasabb a lányok száma, mint a fiúké.

A tanulói bejárási szokásokat vizsgálva több összefüggésre is megkaptuk a választ. Az iskolaválasztásnál az adott korosztály 47,8\%-a választott helyi középiskolát (193fö), 43,1\% más településről jár be reggelente, a viszonylag jó közlekedésnek köszönhetően. A válaszadók 8,2\%-a kollégista (33 fö), akiknek döntő része nem a kistérségből érkezik. Az egyéb ${ }^{33}$ válaszlehetőséget megjelölök aránya nem számottevő, mintegy 1\%. A legtöbb helyi diák a Székács József Evangélikus Általános Iskola és Gimnáziumban van jelen. Ennek oka, hogy itt általános iskolai képzés is folyik, ezért sokan itt folytatják a középiskolai tanulmányaikat is. A kistérségben két olyan iskola müködik, amely ilyen lehetőséget nyújt a tanulóknak. Ez az intézmény valamint a Jankó János Általános Iskola és Gimnázium. E két helyen összesen 69-en töltötték ki a kérdöívet, ebből 45 fő járt ugyanide általános iskolába is, tehát a válaszadók 65,2\%-a. Az egész mintavételt figyelembe véve $79 \%$ járt a lakóhelyén található általános iskolába,

${ }^{33}$ Rokonoknál, ismerősöknél van albérletben, vagy ott lakik. 
9,9\% más település általános iskolájába és 11,1\% ugyanabba az intézménybe, ahova most jár.

A továbbiakban azt vizsgáltuk, hogy a középiskolába való jelentkezés elött a diákok mely szempontokat mérlegelték, valamint mely tényezők befolyásolták őket az iskola kiválasztásában. A válaszadók 21,3\%-ának a szülei és 7,9\%-ának a nagyszülei is ugyanabban az intézményben tanultak, mint most ők. Ez a tényező csak 2,5\%-ban befolyásolta a jelentkezőket. A válaszadók kilenc szempont közül választhattak a kérdőíven, hogy melyek voltak hatással rájuk döntésük során. Eredményül kaptuk, hogy iskolánként más-más tényező befolyásolja az iskolaválasztást. Minden válaszból kitünik, hogy fontos szempont az iskola közelsége a lakhelyhez. A diákokkal való beszélgetés kapcsán az is kiderült, hogy ez a szempont azért ilyen fontos, mert egyre több azon tanulók száma, akiknek a „tanulás után a ház körül a családnak segítenie kell”. Legkevésbé fontos szempontok közé sorolandó az anyagi okok, valamint az egyéb indokok. Ellenben ez a két befolyásoló tényező meghatározó elem a tótkomlósi iskola választása esetén. Tisza Kálmán Közoktatási Intézmény hírneve nem motiválja a tanulók jelentős részét, sőt a tanulási motivációkkal is baj van, ez abból adódik, hogy ők első- vagy másodhelyen nem ide jelentkeztek, csak rossz tanulmányi átlaguk miatt ide kerültek.

Vizsgáltuk az összefüggést az iskolaválasztás és a középiskola elvégzése utáni tervek között. A felmérésben résztvevő diákok 83,9\%-a jelölte meg első helyen a jelenlegi iskoláját. Legtöbb első helyen bejutó a Táncsics Mihály Közoktatási Intézmény és Tehetségközpontban található, a diákok 90,7\%-ának ez volt az első intézmény a jelentkezési lapján. A legkevesebb első helyen bekerülő diák a Tisza Kálmán Közoktatási Intézményben van, itt ez az arány 77\%. Az általános iskolai átlag és a választott középfokú oktatási forma közötti összefüggések vizsgálata során jól látszik az iskolalejtő problémája, miszerint a társadalmilag legpreferáltabb, legelismertebb a gimnázium, ahová kitủnő vagy jó jeggyel érkeznek a gyerekek. A szakközépiskolát választók esetében már elég volt, ha 3,1 4,0 közötti átlaggal rendelkeztek, ezt az iskolatípust inkább a közepes tanulók választották. Míg a szakiskolába jelentkezők között egyre inkább nő a gyenge tanulók aránya. Azonban meglepő, hogy 6 fó jeles eredménnyel a szakiskolai képzés mellett döntött. A társadalom hierarchiáját megmutatja, hogy a legtöbb 4,1 5,0 tanulmányi átlagú diák a Táncsics Mihály Közoktatási Intézmény és Tehetségközpontban tanul. Ebben az intézményben indult a legtöbb gimnáziumi osztály a vizsgált iskolák közül. Legkevesebben a Tisza Kálmán Közoktatási Intézményben vannak, akik jó és jeles bizonyítvánnyal érkeztek. Ez az intézmény indította a legtöbb szakiskolai osztályt.

A teljesítményváltozást vizsgálva megállapíthatjuk, hogy a Táncsicsban és Tótkomlóson a diákok több mint kétszerese rontott az általános iskolai átlagához képest. Azonban azt érdemes hangsúlyozni, hogy csak néhány tizedesjegy változásról van csak szó. A Táncsics esetében a bejövő szint tanulmányi eredményességét és a kimenő szint (érettségi) tanulmányi eredményességét összevetve megállapítható, hogy lényegesebb eltérés nem tapasztalható, 
ugyanakkor azt is hangsúlyozni szükséges, hogy a rontottak viszonylag magas száma statisztikailag abból adódik, hogy az iskola nagyjából felerészben iskoláz be orosházi, valamint kistérségi és kistérségen kívüli tanulókat. A kistérségből és azon kívül érkező tanulók esetében a 9. évfolyamon a tanulmányi visszaesés nagyobb mértékủ volt. Véleményünk szerint ennek az oka, hogy alacsonyabb az ottani általános iskolai oktatás színvonala. Az evangélikus iskolában és a Tisza Kálmán Közoktatási Intézményben viszont megfigyelhető, hogy sikerült mindkét intézményben a tanulók mintegy 35\%-ának megtartania korábbi eredményét. A Tisza Kálmánban vannak a legtöbben, akik javítani is tudtak.

A Jankó János Általános Iskola és Gimnázium, a Székács József Evangélikus Általános Iskola és Gimnázium és a Táncsics Mihály Közoktatási Intézmény és Tehetségközpont gimnazistái vannak a legtöbben, akik föiskolán vagy egyetemen szeretnének tanulni a középiskola befejezése után. Munkába állni a Tisza Kálmán Közoktatási Intézmény diákjainak 31,6\%-a szeretne végzés után. Összességében a tanulók 21,8\%-ának még nincs határozott elképzelése arról, hogy milyen irányban szeretné folytatni életét a középiskola befejezése után.

Arra a kérdésre, hogy szüleid várhatóan meddig finanszírozzák a tanulmányaidat, a válaszadók legnagyobb részének, 53,5\%-ának szülei még nem döntötték el, hogy meddig támogatják gyermekük iskolázását. 11,6\% mester-, 12,6\% az alapdiploma eléréséhez tervezi hozzásegíteni gyermekét. Kevésbé jellemző a technikusi végzettség, a válaszadók mindössze $2 \%$-a jelölte meg.

Jól kivehető a társadalmi lejtő, hogy a magasabb iskolai végzettséggel rendelkező szülők gyermekei választották továbbtanulási intézményként gimnáziumot, míg az alacsonyabbaké inkább szakközépiskolában vagy szakiskolában tanulnak. Jellemzően a diákok legalább ugyanolyan fokú, vagy magasabb végzettséget szeretnének elérni, mint szüleik. Így bizonyos értelemben az iskolaválasztás társadalmi szokásai egyfajta indikátort mutatnak, hogy az adott társadalmi rétegek milyen képzési típust preferálnak.

Az adott válaszokból kiderült, hogy a szakiskolai osztályokba a 8 általánossal, vagy szakmunkás képesítéssel rendelkező szülök gyermekei járnak. A szakközépiskolát már inkább a szakmunkás vagy érettségi vizsgát letevő szülök gyermekei választják. A gimnáziumi képzés esetén a szakmunkás és érettségizettek aránya szinte azonos, de viszonylag magas a diplomások száma is. Összehasonlítva a két szülő iskolai végzettségét, megállapíthatjuk, hogy jellemzően azonos képzettségi fokkal rendelkeznek. A családok 20,7\%-ának esetében az apa végzettsége magasabb, 27,3\%-nál pedig az anya rendelkezik magasabb képzettséget tanúsító bizonyítvánnyal. A családok 52\%-ánál megegyezik a szülőpár végzettsége.

A szakközépiskolás és szakiskolás diákok szüleinek jelentős része fizikai munkát végez, vagy munkanélküli. A társadalmi lejtő egyben az iskolalejtőt is indukálja.

A következőkben a szociális hátteret vizsgáltuk. A diákok 56,25\%-ának volt már legalább az egyik szülője munkanélküli, 12,5\%-uknak jelenleg is munkanélküli az egyik, vagy mindkét szülője. A munkanélküliség legföképpen a 
szakiskolába járó diákok szüleit érinti. A szakközépiskolában tanulók családjában 33,5\%-ában van jelen a munkanélküliség, míg a gimnáziumba járók szüleinél majdnem $75 \%$-os a foglalkoztatottsági arány.

Minden intézmény esetében átlagosan 4 fö él együtt egy közös háztartásban. A kérdőívek kiértékelése és az összefüggés vizsgálatok során kiderült, hogy minél szegényebb egy család, annál több a gyerekek száma. A nagyobb hírnévvel rendelkező intézményekbe olyan diákok járnak, akik átlagosan kevesebben laknak egy közös háztartásban. A családok 11,9\%-a kettőnél több generációs, a gyerekek a szülők mellett a nagyszülőkkel is együtt élnek. A diákok 2,7\%-a egyáltalán nem lakik együtt a szüleivel (testvérrel, nagyszülöknél vagy rokonoknál lakik). A vizsgálatban szereplök 16,2\%-a egyke, 39,9\%-nak egy testvére van, 24,3\%-nak kettő, 29,7\% él olyan családban, amelyben a gyerekek száma 3 vagy több.

A családok lakhatósági lehetőségeit vizsgálva a válaszadók legjelentősebb része saját családi házában él, 10,1\% saját tulajdonú lakásban; összesen a családok 6,4\% bérel házat vagy lakást. Az átlagos szobaszám három. A diákok 71,8\%-ának van saját szobája, 24,8\%-uknak testvérrel közös a szobája.

A tanulók családjának anyagi helyzetét a tulajdonukban lévő tartós fogyasztási cikkek által próbáltuk meg behatárolni, illetve konkrétan rákérdeztünk, hogy saját megítélésük szerint milyen is az ő anyagi helyzetük. A családok 88,6\%-a rendelkezik asztali számítógéppel. 48,3\%-uk emellett laptoppal is, és csaknem minden PC-vel rendelkező lakásban van internet is. A televízió, automata mosógép, mikrohullámú sütő, DVD lejátszó megtalálható a lakások szinte mindegyikében. A mosogatógép megléte kevésbé jellemző, 25,9\%-uk tulạjdonában található meg. 69,3\% használ saját személygépkocsit, nyaralója a családok 10,9\%-ának van.

A válaszadók $66,6 \%$-a állítja, hogy családjának anyagi helyzete átlagos, $0,5 \%$ szerint az anyagi helyzetük sokkal rosszabb mint az átlag, míg 5,5\% bevallása szerint sokkal jobb, $6,9 \%$ pedig nem tudja.

Fontos még megvizsgálni az intézmények beiskolázási vonzáskörzetét. A tótkomlósi Jankó János Gimnázium tanulóinak 58,6\%-a helyi diák. További 10,3\%-uk az Orosházi kistérségben lakik. Nagyérről, Ambrózfalváról, Pitvarosról és Csanádalbertiröl érkezett a tanulók 31\%-a. Székács József Általános Iskola és Gimnáziumban a diákok 80\%-a helyi. A kistérségből 15\% érkezett. A tanulók 5\%a két településről érkezett Székkutasról és Kiscsákóról. A Táncsics Mihály Közoktatási Intézmény és Tehetségközpontban a 54,7\%-ot képviselnek a helyi tanulók. A kistérség települései a diákok lakhelyének 24,8\%-át teszik ki. További 13,2\% érkezik Nagymágocsról, Székkutasról, és Dévaványáról. A fennmaradó 7,3\%-on 16 település diákjai osztoznak. A Tisza Kálmán Közoktatási Intézményben a helyi diákok aránya $35,1 \%$. Ezen felül a tanulók 36,8\%-a jött az Orosházi kistérségböl. 14,9\% érkezett az alábbi településekröl: Nagyszénás, Székkutas, Kaszaper, Nagymágocs, Mezőhegyes. A további 13,2\%-ot 16 település diákjai jelentik. 


\section{4. ÖSSZEFOGLALÁS}

A hipotézisek vizsgálata a következő:

1. A vizsgált intézmények közül két iskolában folyik a gimnáziumi képzés mellett általános iskolai is. Ilyen lehetőséget a tótkomlósi Jankó János Általános Iskola és Gimnázium, valamint a Székács József Evangélikus Általános Iskola és Gimnázium biztosít. A válaszadók 65,2\%-a kezdte itt az első osztályt és várhatóan itt is fog végezni. Ezen intézmények előnye, hogy egy megszokott környezetben folytathatják tanulmányaikat a diákok. Tehát ez a megállapítás igaznak minősül.

2. A válaszadók mintegy 29,2\%-ának járt a szülöje vagy a nagyszülöje ugyanebbe az iskolába, mint ők. Ez a szempont mindössze csak 2,5\%-ban befolyásolta őket a választásukban. $\mathrm{Az}$ adott válaszok alapján a leglényegesebb tényezőnek a közeli lakhely bizonyult. Így ez a hipotézisünk sajnos nem bizonyult valósnak.

3. A diákok nagy része abban a középiskolában tanul, amelyet első helyen jelölt meg a jelentkezési lapján. A jó, jeles átlaggal rendelkezők gimnáziumi képzésben vesznek részt, míg a gyenge teljesítményüek szakiskolába járnak. Ez a feltételezésünk helyesnek bizonyult, ugyanis aki a jövőjét felsőoktatási intézményben képzeli el, az gimnáziumot vagy szakközépiskolát választott, ellenben akik munkába szeretnének állni a középiskolás évek után, azok szakiskolai osztályba jelentkeztek.

4. Jobb anyagi körülmények között élő családok gyermekei gimnáziumban vagy szakközépiskolában tanulnak tovább, míg a szegényebb és hátrányos helyzetü családok gyermekei a szakiskolát választják. A munkanélküliség hatással van az iskolaválasztásra, itt is a szakiskolások között volt a legtöbb munkanélküli szülö. Ezek alapján elmondhatjuk, hogy a családi háttér befolyásolja a tanulók teljesítményét, azonban a családok lakhatási lehetőségei nem mutatnak egyértelmű összefüggést a szociális körülmény és az egyén iskolaválasztása között, így ezt a feltevésünket nem feltétlenül látjuk igazoltnak.

5. A magasabb iskolai végzettséggel rendelkező szülök gyermekei középiskolai tanulmányaikat gimnáziumban kezdik, míg az alacsonyabb végzettségüeké szakiskolában. A magasabb státusú családi háttérrel rendelkezők hajlamosabbak a magasabb iskolai szint elérésére, míg az alacsonyabb családi hátterủek, a gyermekeik számára a szakiskolában látják a társadalmi felemelkedés lehetőségét. A szülők iskolázottsági különbségei és a gyermekeik iskoláztatási perspektíváit befolyásoló jellemzők között szoros párhuzam figyelhető meg. A kapott eredmények alapján ez a hipotézis beigazolódott.

6. A legtöbb helyi diák a Székács József Evangélikus Általános Iskolában és Gimnáziumban van, itt ez az arány $80 \%$. A legkevesebb helyi diák a Tisza Kálmán Közoktatási Intézményben van, az ő arányuk 35,1\%, továbbá itt található meg a legtöbb az Orosházi kistérségböl érkező diák 36,8\%. A Székács József Evangélikus iskolában van a legkevesebb kistérségen kívüli 
településen lakó tanuló, mindössze csak 5\%. Így itt ez a hipotézis nem bizonyult igaznak. A további három intézményben viszont igen. A Táncsicsban $20,5 \%$, a Tisza Kálmánban $28,1 \%$, míg Tótkomlóson $31 \%$ nem az Orosházi kistérségből érkezett. A leggyakoribb települések: Nagymágocs, Székkutas, Kaszaper. De a nagyobb településekröl is vannak diákok, mint például Battonya, Békéscsaba, Mezőkovácsháza, Szarvas és Szentes.

A középiskolába történő jelentkezésnél a diákoknak az egyik legfőbb szempont, hogy az iskola közel legyen a lakóhelyhez. Ez a motiváció mind a négy intézménynél az első négy döntést befolyásoló szempont között szerepelt.

A tanulók iskolaválasztását a középiskola elvégzése utáni terveik is nagyban befolyásolják. A gimnáziumba járó tanulók közül a legtöbben föiskolán, vagy egyetemen szeretnének továbbtanulni. Ezzel szemben, a középiskola befejezése után a szakiskolában végzett diákok többsége munkába kíván állni.

A magasabb iskolai végzettséggel rendelkező szülők gyermekei gimnáziumban, míg az alacsonyabb végzettségủeké inkább szakközépiskolába vagy szakiskolába tanul tovább. Megállapítható, hogy a társadalmi státuszból eredő iskolaválasztási szokások befolyásolják a középiskolai továbbtanulást. Ez a társadalmi egyenlötlenségből eredő lejtő az alapja az iskolalejtőnek is.

A középfokú oktatás képzési területeinek hierarchikus felépítése (gimnázium, szakközépiskola, szakiskola) a tanulók összetételével mereven leképezi a társadalmi különbségeket, és az oktatás színvonalbeli különbségeivel konzerválja a társadalmi egyenlötlenséget (Liskó 2008).

A szociális háttér vizsgálata során megállapítható, hogy a munkanélküliség legfőképpen a szakiskolába járó diákok családjában van jelen. Átlagosan 4 fö él együtt egy közös háztartásban, viszont minél több a gyerekek száma, annál szegényebb a család. A válaszadók több mint fele $(66,6 \%)$ állítja, hogy megítélése szerint családjának anyagi helyzete átlagos.

Az intézmények beiskolázási vonzáskörzete az Orosházi kistérség területén is túlível, sőt elmondható, hogy nemcsak a megyéböl, de a szomszédos megyékböl is ide vonzza a diákokat.

\section{IRODALOMJEGYZÉK}

Andor M. (1998): Középiskola-választás. OKTK kutatása. Magyar Tudományos Akadémia Szociológiai Intézete. pp. 1-17.

Horváth Gy. (2004): A kérdöíves módszer. Müszaki Könyvkiadó. Budapest, pp. 24-48.

Huzsvai L. (2011): Biometriai módszerek az SPSS-ben. SPSS alkalmazások. Debreceni Egyetem Mezőgazdaságtudományi Kar. Debrecen. pp. 3-5.

Liskó I. (2008): Szakképzés és lemorzsolódás. Zöld könyv a magyar közoktatás megújjításáért. Ecostat. Budapest. pp. 95-121.

Majoros P. (2004): A kutatásmódszertan alapjai. Perfekt Gazdasági Tanácsadó. Oktató és Kiadó Részvénytársaság. pp. 29-121.

Róbert P. (2004): Iskolai teljesítmény és társadalmi háttér nemzetközi összehasonlításban. In. Kolosi et. al. (2004): Társadalmi Riport 2004. TÁRKI. Budapest, pp. 193-205. 